\title{
Akılcı Antibiyotik Kullanımı Konusunda Adnan Menderes Üniversitesi Uygulama ve Araştırma Hastanesi Hekimlerinin Bilgi ve Farkındalık Düzeylerinin Belirlenmesi
}

\author{
Determination of the Knowledge and Awareness Levels of Adnan Menderes University \\ Application and Research Hospital Doctors About Rational Use of Antibiotics
}

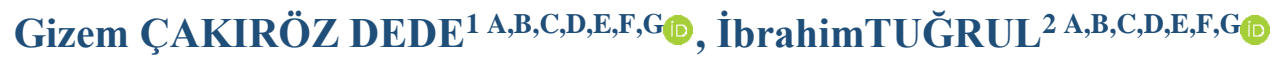 \\ ${ }^{1}$ Aydın Adnan Menderes Üniversitesi Sağlık Bilimleri Enstitüsü, Tıbbi Farmakoloji Anabilim Dalı, Aydın, Türkiye \\ ${ }^{2}$ Aydın Adnan Menderes Üniversitesi Tıp Fakültesi, Tıbbi Farmakoloji Anabilim Dalı, Aydın, Türkiye
}

ÖZ

\begin{abstract}
Amaç: Ülkemizde ve dünyada reçete edilen ilaçlar arasında en sık reçete edilen ilaç gruplarından biri antibiyotiklerdir. Uygunsuz antibiyotik kullanımı dirençli mikroorganizmaların yaygınlaşması ve ekonomik kayıplara neden olmaktadır. $\mathrm{Bu}$ çalışmanın amacı; hekimlerde akılcı antibiyotik kullanım bilgi ve tutum düzeyi konusunda farkındalı̆ın araştırılması ve hekimlerde akılcı antibiyotik kullanımı konusunda farkındalığı artırmaya yönelik stratejilerin belirlenmesidir.

Yöntem: Çalışmamız Aydın Adnan Menderes Üniversitesi Uygulama ve Araştırma Hastanesi'ndeki hekimlere yapılmışır. Tanımlayıcı tipte kesitsel bir çalışmadır. Çalışmaya 2018 yılı mayıs -haziran aylarında anket görüşmesini kabul eden hekimler dahil edilmiştir. Çalışmaya 203 kişi davet edilmiştir. Toplam 147 (\%72.4) kişi anket sorularına cevap vermeyi kabul etmiş olup araştırmaya dahil edilmişlerdir. Anket 27 sorudan oluşmaktadır.

Bulgular: Değerlendirmelerimiz sonucunda hekimlerin \%89.1'inin akılcı antibiyotik kullanımı hakkında bilgi sahibi olduğu görülmektedir. Antibiyotik seçerken dikkate alınan kriterler incelendiğinde en az maliyet (\%42.9); en çok etkililik (\%83.0) olarak tespit edilmiştir.

Sonuç: Çalışmamızda, akılcı antibiyotik kullanımı politikaları kapsamında hekimlerin mezuniyet öncesi ve mezuniyet sonrası eğitimine önem verilmesi, eğitimin sürekli ve gerçek hayata uygun olması, hekimlerin hastalarına daha fazla zaman ayırıp iyi iletişim kurması ve hastalarını bilgilendirmelerinin, akılcı antibiyotik kullanımı açısından olumlu sonuçlar elde edilmesine büyük katkısı olacağını düşünmekteyiz.
\end{abstract}

Anahtar Kelimeler: Akılcı antibiyotik kullanımı, Akılcı ilaç, Antibiyotik, Hekim.

\section{ABSTRACT}

Objective: One of the most commonly prescribed drug groups is antibiotics in our country and in the world. Inappropriate use of antibiotics leads to widespread resistant microorganisms and economic losses. The purpose of this study is; searching awareness about the knowledge and attitude level of rational antibiotic use in physicians and to identify strategies to raise awareness of the rational use of antibiotics in physicians.

Methods: Our study was conducted to physicians in Adnan Menderes University Application and Research Hospital. It is a descriptive type cross-sectional study. The study included physicians who accepted the survey interview in May- June 2018. 203 people have been invited to study. A total of 147 (72.4\%) people agreed to answer the questionnaire and were included in the study. The survey consists of 27 questions.

Results: As a result of our evaluations, it is seen that \% 89.1 of the physicians have knowledge about rational antibiotic use. About the criteria taken into consideration when choosing antibiotics, the least common is cost (42.9\%); while the most common is effectiveness $(83.0 \%)$.

Conclusion: In this study, we believe that giving importance to pre-graduate and post-graduate education of physicians regarding rational antibiotic use policies, making this education continuous and realistic, developing the communication level

Sorumlu Yazar: Gizem ÇAKIRÖZ DEDE

Aydın Adnan Menderes Üniversitesi, Sağlık Bilimleri Enstitüsü, Tıbbi Farmakoloji Anabilim Dalı, Aydın, Türkiye gizemcakiroz@hotmail.com

*Bu makale 04-07 Kasım 2019'da düzenlenen 25. Ulusal Farmakoloji Kongresi'nde poster olarak sunulmuştur.

Geliş Tarihi: 25.02.2020 - Kabul Tarihi: 15.06.2020 
between the physicians and their patients by sparing more time to those patients and informing them better will contribute greatly to achieving positive results in terms of rational antibiotic use.

Key words: Rational antibiotic use, Rational drug, Antibiotic, Physician.

\section{GİRIŞ}

Dünya Sağlık Örgütü (DSÖ) Nairobi Konferansı'nda (1985) akılcı ilacı; hastaların kişisel özelliklerine ve hastalığa ait bulgulara göre uygun ilacı, uygun miktarda ve zaman aralığında, en uygun maliyetle ve kolayca uygulayabilme şeklinde tanımlamıştır. Akılcı ilacın bütün kullanım ilkeleri bu tanım içerisinde bulunmaktadır. Akılcı ilacın temel ilkeleri; endikasyonun uygunluğu, ilacın doğru seçimi, uygun hasta, doğru doz ve yeterli zaman aralığında hastayı doğru bilgilendirme parametrelerinden oluşur (1).

Akılcı antibiyotik kullanımı, antibiyotik uygulanacak hastaya konacak tanının doğru olması ve buna göre tedavi planlamasının yapılmasıyla başlar. Daha sonra verilecek antibiyotiğin doğru seçimi, hastaya reçeteyi yazma, tedavi sürecine başlama, hastaya bu süreç ile alakalı bilgilendirme yapma, gerekli uyarılarda bulunma, tedavi sürecinin takibi ve hastayı aralıklarla muayene kontrolüne çağırma şeklindedir (2). Antibiyotiklere karşı direnç gelişmesi birçok ciddi soruna yol açmaktadır. Antibiyotiklere karşı direnç gün geçtikçe artmaktadır. Antibiyotik direncinin sebep olduğu sorunlardan dolayı akılcı antibiyotik kullanımına olan ihtiyaç artmaktadır $(3,4)$.

$\mathrm{Bu}$ çalışmada akılcı antibiyotik konusunda hekimlerin bilgi ve farkındalık düzeylerinin belirlenmesine yönelik anket soruları hekimlere yöneltilmiş ve durum tespiti yapılmaya çalışılmıştır.

\section{GEREÇ VE YÖNTEMLER}

Çalışmamız 2018 yılı mayıs-haziran ayları arasında yapılmıştır. Araştırma evreni Adnan Menderes Üniversitesi Uygulama ve Araştırma Hastanesi'ndeki hekimlerden oluşmuştur. Veriler, araştırmacılar tarafından hazırlanan akılcı antibiyotik kullanımı bilgi ve tutumunu değerlendiren 27 soruluk bir anketle toplanmıştır. Anket formları Adnan Menderes Üniversitesi Uygulama ve Araştırma Hastanesi'nde görev yapan hekimlere dağıtılmıştır.

Adnan Menderes Üniversitesi Uygulama ve Araştırma Hastanesi'ndeki dahili ve cerrahi tıp bilimlerinde görev yapan tüm hekimlere akılcı antibiyotik kullanım bilgi ve tutum düzeyi konusunda farkındalığın araştırılması amacıyla anket formları dağıtılmıştır.

Anketimizin ilk bölümünde hekimlere mesleki ve kişisel özelliklerle alakalı açık ve kapalı uçlu sorular yöneltilmiştir. Bu kısımda hekimlere cinsiyeti, yaşı, ne kadar süredir hekim oldukları, dahili ve cerrahi tıp bilimlerinden hangisinde uzman oldukları ya da uzmanlık eğitimi aldıkları sorulması amaçlanmıştır. Anketin ikinci bölümünde "antibiyotik reçete ederken dikkat edilen durumlar", "reçete edilen antibiyotik ile ilgili hastayı bilgilendirme", "hastaya verilen antibiyotik tedavisinin sonuçlarını takip etme", "ilaçlarla ilgili advers (yan) etki ortaya çıktığında bildirim yapma", "hastanızın istediği antibiyotiği reçete etme durumu", "antibiyotik seçerken dikkate alınan kriterler", "akılcı antibiyotik kullanımı konusunda bilgi sahibi olup olmama", "akılcı antibiyotik kullanımı konusunda seminer, eğitim almak isteme" ile ilgili sorulara yer verilmiştir.

Dağıtılan anket formları toplanarak istatistiksel analizi yapılmıştır. 
Çalışmamız Adnan Menderes Üniversitesi Tıp Fakültesi Dekanlığı Girişimsel Olmayan Klinik Araştırmalar Etik Kurulu'ndan alınan onay sonrası yapılmıştır (Tarih:12/4/2018 Karar no:9 Protokol no:2018/1376).

Araştırma sonucunda ulaşılan veriler SPSS (Statistical Packege for Social Science) for Windows 25.0 programı ile analiz edilmiştir. Veriler \%95 güven aralığı içinde, anlamlılık $\mathrm{p}<0,05$ düzeyinde değerlendirilmiştir. Verileri değerlendirirken tanımlayıcı istatistik metotlarından sayı, yüzde, ortalama ve standart sapmadan yararlanılmıştır.

\section{BULGULAR}

Çalışmamızda anketimizi doldurmayı kabul etmiş 147 hekim değerlendirilmiştir. Araştırmaya katılan katılımcıların sosyo-demografik özellikleri değerlendirildiğinde; çalışmamızda 147 hekimin \%41.5'i kadın, \%58.5'i erkektir. Katılımcıların \%69,4'ü 24-30 yaş, \%19.7'si 30-40 yaş, \%5,4'ü 41-50 yaş, \%4,1'i 51-60 yaş, \%1,4'ü 61-65 yaş aralığındaki hekimlerden oluşmaktadır. Mesleki tecrübe incelendiğinde ise 1-15 yıllık mesleki tecrübeye sahip hekimlerin oranının \%74.1 olduğu tespit edilmiştir (Tablo 1).

Tablo 1. Katılımcıların Sosyo-Demografik Özellikleri

\begin{tabular}{lccc}
\hline Özellikler & & Sayı(n) & Yüzde(\%) \\
\hline Cinsiyet & Kadın & 61 & 41.5 \\
& Erkek & 86 & 58.5 \\
\hline Yaş & $24-30$ & 102 & 69.4 \\
& $31-40$ & 29 & 19.7 \\
& $41-50$ & 8 & 5.4 \\
& $51-60$ & 6 & 4.1 \\
& $61-65$ & 2 & 1.4 \\
\hline Mesleki Tecrübe & 1 yıldan az & 20 & 13.6 \\
& $1-5$ yıl & 79 & 53.7 \\
& $6-15$ yıl & 30 & 20.4 \\
& $16-20$ yıl & 6 & 2.1 \\
& $21-25$ yıl & 4 & 2.7 \\
& $26-30$ yll & 4 & 2.7 \\
\hline Uzmanlık Alanı & Cerrahi Tip Bilimleri & 4 & 32.0 \\
& Dahili Tip Bilimleri & 47 & 68.0 \\
\hline
\end{tabular}

Hekimlerin antibiyotik reçete etme nedenleri incelendiğinde, $\% 45^{\prime}$ 'i profilaksinin, $\% 95$ 'i tedavinin, \% 7.5'i hastanın isteğinin neden olduğunu ifade etmiştir. Hekimlere akılcı antibiyotik kullanımı hakkında bilgi sahibi olup olmadıkları sorulduğunda; \%10.9'unun akılcı antibiyotik kullanımı hakkında bir bilgiye sahip olmadığı, \%89.1'inin ise akılcı antibiyotik kullanımı hakkında bilgi sahibi olduklarını belirttikleri saptanmıştır.

Antibiyotik yazarken dikkat edilen durumlar değerlendirildiğinde hastanın gebelik durumuna hekimlerin \%78.2'sinin, hastanın alerjik öyküsüne \%74.1'inin, hastanın yaşına hekimlerin \%52.4'ünün her zaman dikkat ettikleri; hekimlerin \%29,9'unun sigara/alkol kullanımı, yan destek ürünler ve bitkisel ürün/ilaç kullanımına, \%23.8'inin ilaç fiyatlarına hiç dikkat etmedikleri belirlenmiştir (Tablo 2). 
Tablo 2. Antibiyotik Reçete Ederken Dikkat Edilen Durumlar

\begin{tabular}{|c|c|c|c|c|c|c|c|}
\hline & Her Zaman & \multicolumn{2}{|c|}{ Sıklıkla } & \multicolumn{2}{|c|}{ Bazen } & \multicolumn{2}{|c|}{ Hiç } \\
\hline Say1(n) & Yüzde(\%) & Sayı(n) & Yüzde(\%) & Sayı(n) & Yüzde(\%) & Sayı(n) & Yüzde(\%) \\
\hline Hastanın yaşı & 52.4 & 50 & 34.0 & 15 & 10.2 & 5 & 3.4 \\
\hline Hastanın cinsiyeti & 14.3 & 21 & 14.3 & 50 & 34.0 & 55 & 37.4 \\
\hline $\begin{array}{l}\text { Hastada kronik } 72 \\
\text { hastalık olup olmaması }\end{array}$ & 49.0 & 54 & 36.7 & 20 & 13.6 & 1 & 0.7 \\
\hline $\begin{array}{l}\text { Hastanın kullandığ } \\
\text { diğger ilaçlar }\end{array}$ & 46.3 & 56 & 38.1 & 21 & 14.3 & 2 & 1.4 \\
\hline $\begin{array}{ll}\text { Hastanın alerjik } & 109 \\
\text { öyküsünün varlığ } & \end{array}$ & 74.1 & 28 & 19.0 & 10 & 6.8 & 0 & 0.0 \\
\hline İlaç fiyatı & 9.5 & 31 & 21.1 & 67 & 45.6 & 35 & 23.8 \\
\hline $\begin{array}{l}\text { Hastanın ilaç } \\
\text { kullanım tecrübesi }\end{array}$ & 13.6 & 48 & 32.7 & 60 & 40.8 & 19 & 12.9 \\
\hline $\begin{array}{ll}\text { Hastanın } & 21 \\
\text { sosyokültürel düzeyi } & \end{array}$ & 14.3 & 52 & 35.4 & 58 & 39.5 & 16 & 10.9 \\
\hline Alkol/sigara kullanımı 12 & 8.2 & 29 & 19.7 & 62 & 42.2 & 44 & 29.9 \\
\hline Gebelik durumu & 78.2 & 21 & 14.3 & 8 & 5.4 & 3 & 2.0 \\
\hline $\begin{array}{l}\text { Yan destek } \\
\text { ürünler ve } \\
\text { bitkisel ürün/ilaç kullanımı }\end{array}$ & 12.2 & 27 & 18.4 & 58 & 39.5 & 44 & 29.9 \\
\hline
\end{tabular}

Reçete edilen antibiyotik hakkında hastaya bilgi verme durumu değerlendirildiğinde hekimlerin \%36.1'inin her zaman bilgi verdiği, \%48.3'ünün sıklıkla bilgi verdiği, \%15'inin bazen bilgi verdiği, \%0.7'sinin hiç bilgi vermediği tespit edilmiştir. Hastaya reçete edilen antibiyotik hakkında verilen bilgiler tablo 3 'te belirtilmiştir. Hekimler tarafından verilen bilginin hastalar tarafından tekrar edilmesi isteğinin oranları incelendiğinde \%36.1'inin tekrarı istediği, \%63.9'un tekrarı istemediği tespit edilmiştir. Hastaların tekrar etmesini istemeyen hekimlerin neden istemediği tablo 4'de belirtilmiştir. Antibiyotik kullanımı hakkında hekim bilgilendirme yaparken hekimlerin karşılaştığı zorluklar değerlendirildiğinde \% 72.8 ' i hastanın sosyo-kültürel düzeyi, \%69.4'ü iş yoğunluğu, \%61.2' si muayene süresinin yeterli olmaması, \%13.6' sı ilaç hakkında yeterli bilgi düzeyine sahip olmama olarak belirtmişlerdir.

Hekimlerin hastaya verdiği antibiyotik tedavisinin sonuçlarını takip etme durumu değerlendirildiğinde ise hekimlerin \%51'inin tedaviyi takip ettiği, \%49'unun tedaviyi takip etmediği görülmüştür. İlaçlar ile ilgili yan etki ortaya çıktığında ise hekimlerin \%36.7'sinin bildirim yapmakta olduğu ve \%63.3'unun bildirim yapmadığı belirlenmiştir. İlaç yan etkileri ortaya çıktığında bildirim yapılan kurum olan TÜFAM'1 hekimlerin \%42.9'unun bildiği belirlenmiştir. Hekimlerin hastanın istediği antibiyotiği reçete etme durumu 
değerlendirildiğinde hekimlerin \%4.1'i sıklıkla, \%62.4 'ü bazen reçete ettiklerini ; \%43.5' i ise hiçbir zaman reçete etmediklerini belirtmiştir.

Tablo 3.Hekimlerin Hastaya Reçete Ettikleri Antibiyotik Hakkında Verdikleri Bilgiler

\begin{tabular}{|c|c|c|c|c|c|c|c|c|}
\hline & \multicolumn{2}{|c|}{ Her Zaman } & \multicolumn{2}{|c|}{ Sıklıkla } & \multirow{2}{*}{\multicolumn{2}{|c|}{$\begin{array}{c}\text { Bazen } \\
\text { 1(n) Yüzde(\%) }\end{array}$}} & \multirow{2}{*}{\multicolumn{2}{|c|}{$\begin{array}{c}\text { Hiç } \\
\text { Sayı(n) Yüzde(\%) }\end{array}$}} \\
\hline & Sayı(n) & Yüzde(\%) & Sayı(n) & Yüzde(\%) & & & & \\
\hline Kullanım şekli & 106 & 72.1 & 34 & 23.1 & 6 & 4.1 & 1 & 0.7 \\
\hline Kullanım süresi & 104 & 70.7 & 35 & 23.8 & 7 & 4.8 & 1 & 0.7 \\
\hline Kullanım periyodu & 89 & 60.5 & 44 & 29.9 & 13 & 8.8 & 1 & 0.7 \\
\hline İlaç/ilaç etkileşimleri & 17 & 11.6 & 38 & 25.9 & 75 & 51.0 & 17 & 11.6 \\
\hline İlaç/besin etkileşimleri & 15 & 10.2 & 32 & 21.8 & 74 & 50.3 & 26 & 17.7 \\
\hline İlaç yan etkileri & 31 & 21.1 & 55 & 37.4 & 50 & 34.0 & 11 & 7.5 \\
\hline İlaç etki mekanizması & 7 & 4.8 & 14 & 9.5 & 62 & 42.2 & 64 & 43.5 \\
\hline
\end{tabular}

Tablo 4. Hekimlerin Hastaya Verilen Bilgiyi Tekrar Ettirmeme Nedenleri

\begin{tabular}{lcc}
\hline Hastaya bilgiyi tekrar ettirmemenizin nedeni (n:94) & \\
\hline Zaman yetersizliği & Sayı(n) & Yüzde(\%) \\
\hline Hastanın sosyo-kültürel düzeyi & 66 & 70.2 \\
\hline Gerekli olmadığını düşündüğü için & 19 & 20.2 \\
\hline $\begin{array}{l}\text { Hastanın reçete edilen ilacı daha } \\
\text { önce kullanmış olması }\end{array}$ & 22 & 23.4 \\
\hline
\end{tabular}

Hekimlerin hastaya verdiği antibiyotik tedavisinin sonuçlarını takip etme durumu değerlendirildiğinde ise hekimlerin \%51'inin tedaviyi takip ettiği, \%49'unun tedaviyi takip etmediği görülmüştür. İlaçlar ile ilgili yan etki ortaya çıktığında ise hekimlerin \%36.7'sinin bildirim yapmakta olduğu ve \%63.3'unun bildirim yapmadığı belirlenmiştir. İlaç yan etkileri ortaya çıktığında bildirim yapılan kurum olan TÜFAM'1 hekimlerin \%42.9'unun bildiği belirlenmiştir. Hekimlerin hastanın istediği antibiyotiği reçete etme durumu değerlendirildiğinde hekimlerin \%4.1'i sıklıkla, \%62.4 'ü bazen reçete ettiklerini; \%43.5' i ise hiçbir zaman reçete etmediklerini belirtmiştir.

Hekimlere etkililik, maliyet, uygunluk ve güvenlilik kriterlerinden antibiyotik seçerken hangisi ve/veya hangilerini göz önüne aldıkları sorulduğunda; hekimlerin \%42.9'unun maliyet, $\% 83.0$ ‘ünün etkililik, \%80.3'ünün uygunluk ve \%75.5'inin güvenlilik kriterine dikkat ettikleri saptanmıştır. Hekimlerin akılcı antibiyotik kullanımı ile ilgili bilgi edindikleri kaynaklar değerlendirildiğinde $\% 6.5$ 'i mezun olduğu üniversiteden, \%48.9'u seminer programlarından, \%19.8' i internetten, \%11.5'i de ilaç firmalarından olduğunu belirtmişlerdir. Hekimlere akılcı antibiyotik kullanımı konusunda seminer eğitim almayı isteme konusunda fikri sorulduğunda \%63.3'ünün eğitim veya seminer almayı istediği tespit edilmiştir. Akılcı antibiyotik konusunda yeterli bilgiye sahip olunamamasının nedenleri tablo 5'de incelenmiştir. 
Adnan Menderes Üniversitesi Sağllk Bilimleri Fakültesi Dergisi 2021: 5(2); 333-341

Journal of Adnan Menderes University Health Sciences Faculty

Tablo 5. Akılcı Antibiyotik Kullanımı Hakkında Bilgi Eksikliğinin Nedenleri

\begin{tabular}{lcc}
\hline Yüzde(\%) & Sayı(n) & \\
\hline Farkındalığın yetersiz olması & & 64.6 \\
\hline Eğitim programlarının yetersiz olması & 95 & 53.1 \\
\hline Kaynakların yetersiz olması & 78 & 19.0 \\
\hline Hekimlerin eğitime yeteri kadar zaman ayıramaması & 28 & 70.7 \\
\hline
\end{tabular}

\section{TARTIŞMA}

Çalışmamızdaki katılımcıların \%41.5'inin kadın, \%58.5'inin erkektir. Mesleki tecrübe incelendiğinde ise 1-15 y1llık mesleki tecrübeye sahip hekimlerin oranı \%74.1 olduğu tespit edilmiştir. 'Saygılı ve Özer'in (2015) 'yapmış oldukları çalışmada araştırmaya dahil olan hekimlerden \%67.8'ini erkekler, \%32.2'sini kadınlar oluşturmuştur. 1-15 yıl mesleki tecrübeye sahip katılımcıların oranı \%71.2 saptanmıştır (5). Bu özellikler değerlendirildiğinde katılımcıların cinsiyet oranları ve mesleki tecrübe oranları iki çalışmada da uyumludur. Çalışmamızdaki katılımcıların oranı mesleki olarak genç düzey (1-5 yıl) tecrübeye sahip hekimlerden oluşmuştur. Bu çalışmamızın sonuçlarının katılımcıların gelecekteki mesleki tecrübelerinde pozitif etki oluşturacağını düşünmekteyiz.

Hekimlerin antibiyotik reçete etme sonuçları değerlendirildiğinde hastalara, sıklıkla antibiyotik verenlerin oran $1 \% 32.7$, bazen antibiyotik verenlerin oranı ise $\% 63.9$ olduğu tespit edilmiştir. 'Şahin ve ark.'ın (2004)', sağlık ocaklarında görev yapan hekimlere yapmış oldukları çalışmada hekimlerin her üç reçetesinden birinde antibiyotik bulunanların oranı \%48.4 iken, her beş reçetesinden üçünde antibiyotik bulunanların oranı \%19.4 olarak saptanmıştır (6). “'Işler ve ark'ın(2019)', yapmış olduğu çalışmada aile hekimlerinin reçetelerindeki antibiyotik oranları 2011 yılında \%35 iken 2017 y1lında \%25 olarak saptanmıştır (7). $\mathrm{Bu}$ veriler incelendiğinde 1. ve 3. basamak sağlık kuruluşlarında görev alan hekimlerin antibiyotik reçete etme oranlarının alınan tedbirler ve eğitimler ile azalma göstermesine rağmen hala yüksek olduğunu düşünmekteyiz.

Çalışmamızda hastaların alkol/sigara kullanımı konusunda hekimlerin \%8.2'si her zaman dikkat ederken \%29.9'u hiçbir zaman dikkat etmediğini belirtmiş, antibiyotik reçete ederken yan destek ürünler ve bitkisel ürün/ilaç kullanım durumuna hekimlerin \%12.2'si her zaman dikkat ederken \%29.9'u hiçbir zaman dikkat etmediğini belirtmiştir. Reçete edilen antibiyotiklerin diğer ilaç ve ürünlerle etkileşime girebilmesi, bitkisel ürün/ilaç, alkol ve sigara kullanımı ilacın farmakokinetik özelliklerinde değişikliğe sebep olabilmektedir. Bu nedenlerle hekimlerin antibiyotik reçete ederken hastaların bitkisel ürün/ilaç, alkol ve sigara kullanımlarını göz önüne almaları gerektiğini düşünmekteyiz.

'Kınalıkaya ve ark.'ın'’(2018) yapmış olduğu çalışmada hekimlere reçete ettikleri ilaçlar hakkında yeterli bilgilendirme yaptıklarını düşünüp düşünmedikleri sorulduğunda hekimlerin \%57,5'inin cevaplarının ' 'evet ' olduğu saptanmıştır. Hekimlere verdikleri bilgiyi hastanın anladığını kontrol edip etmedikleri sorulduğunda hekimlerin \%43,4'ünün 'evet', cevabını verdikleri saptanmıştır (8). Bu bulgular bizim çalışmamızla benzerlik göstermektedir. 
Kenesarı ve Özçakar'ın (2016) yapmış oldukları çalışmada, hasta olan çocukların annelerine antibiyotik kullanımı konusunda kısa süreli bilgilendirme sonrası yapılan değerlendirmede annelerin tutum ve davranışlarında bilgilendirmenin etkili olmadığı saptanmıştır (9). Şahin ve ark.'ın (2019) yapmış olduğu çalışmada antibiyotik kullanımı konusunda bilgilendirme yapılan hastaların antibiyotik kullanımı konusunda bilgilendirme yapılmayan hastalardan antibiyotiğin uygun kullanımı konusunda daha etkin oldukları saptanmıştır (10). Akılcı antibiyotik kullanımı konusunda önemli bir faktör olan hastanın bu konuda daha fazla bilgilendirme ile sürece dahil edilmesinin önemli olacağını düşünmekteyiz.

Hekimlerin hastaya verdiği antibiyotik tedavisinin sonuçlarını takip etme durumu değerlendirildiğinde ise hekimlerin \%51'inin tedaviyi takip ettiği \%49'unun tedaviyi takip etmediği görülmüştür. 'Ergin ve ark.'ın (2014)' yapmış oldukları çalışmada hekimlerin tedavilerinin sonuçlarının değerlendirebilme sorusuna evet diyenlerin oranı $\% 56.9$ bulunmuştur (11). Bu sonuçlara bakıldığında hekimlerin yaklaşık olarak yarısının reçete ettikleri ilacın sonuç değerlendirme ve takiplerini yapmadığı görülmüştür. Kullanılan ilaçların hastanın üzerindeki etkinliliğinin ve meydana gelebilecek yan etkilerinin saptanmasında tedavi takibi önemlidir. Tedavi takibinin yapılmamasının akılcı antibiyotik kullanımı konusunda önemli bir eksiklik olduğunu düşünmekteyiz.

İlaçlar ile ilgili yan etki ortaya çıktığında ise hekimlerin \%36.7'si bildirim yapmakta olduğunu ve hekimlerin \%42.9'u ise bildirim yapacağı kurumu bildiğini belirtmiştir. "Saygılı ve Özer'in (2015) 'çalışmalarında katılımcıların \%64.4'ünün hiçbir zaman ilaç advers etki ile ilgili bildirimde bulunmadıkları görülmüştür. Bildirim yapan hekimler arasında ise sadece birkaç defa bildirim yapanların oranı \%71 olarak saptanmıştır (5).'Kınalıkaya ve ark.'ın' '(2018) yapmış olduğu çalışmada hekimlerin sadece \%23,6'sının advers etki ile ilgili bildirim yaptığı, bildirim yapanların \%96'sının sadece 1-2 kez bildirim yaptığı saptanmıştır(8). $\mathrm{Bu}$ veriler 1şığında hekimlerin büyük çoğunluğunun ilaç yan etki bildirim yapmadığı saptanmıştır. İki çalışma birbiriyle benzerlik göstermektedir.

Çalışmamızda hekimlere etkililik, maliyet, uygunluk ve güvenlilik kriterlerinden antibiyotik seçerken hangisi ve/veya hangilerini göz önüne aldıkları sorulduğunda; hekimlerin \%42.9'unun maliyet, \%83.0 'ünün etkililik, \%80.3'ünün uygunluk ve \%75.5'inin güvenlilik kriterine dikkat ettikleri saptanmıştır.' 'Vançelik ve ark. (2006)" yapmış olduğu çalışmada hekimlerin \%66.4'ünün en çok ilacın etkinliğini dikkate aldıkları belirlenmiştir (12). Ergin ve ark. (2014)'nın'’Pamukkale Üniversitesi'nde yaptığı çalışmada ilaç seçerken en çok dikkat edilen kriter \%94.2 oranında etkinlik olarak bulunmuştur, en az dikkate alınan kriter ise $\% 50.5$ oranında fiyat(maliyet) kriteridir (11).

Öztürk ve ark.'ın (2008) yapmış oldukları çalışmada hekimlerin \%56.1'i tıp eğitimi sırasında akılcı antibiyotik kullanımı konusunda eğitim aldıklarını belirtirken, mezuniyet sonrası akılcı antibiyotik kullanımı konusunda eğitim aldığını belirten hekimlerin oranı \%26.8 olarak saptanmıştır (13). Parlak ve ark'ın (2013) yapmış oldukları çalışmada üniversite mezuniyeti sonrası akılcı antibiyotik kullanımı konusunda eğitim alan hekimlerin oranı \% 31.7 olarak saptanmıştır (14). Machowska ve Stalsby Lundborg'un (2019) yapmış oldukları derlemede 29 Avrupa ülkesindeki son sınıf tıp fakültesi öğrencilerinin ortalama \% 66.1 'i antibiyotik kullanımı konusunda daha fazla bilgi almak istediklerini belirtmişlerdir. Aynı derlemede İngiltere'deki 140 genç hekimle yapılan çalışmada hekimlerin \%5-13'ünün antibiyotik kullanımı konusunda bilgilerinin yeterli olduklarını düşündükleri saptanmıştır (15). 
Çalışmamızda hekimlere akılcı antibiyotik kullanımı konusunda seminer eğitim almayı isteme konusunda fikri sorulduğunda ise \%63.3'ünün eğitim veya seminer almayı istediği tespit edilmiştir. Akılcı antibiyotik kullanımı konusunda mezuniyet sonrasında eğitimlerin devam etmesinin önemli olduğunu düşünmekteyiz.

Akılcı antibiyotik konusunda bilgi eksikliğinin nedeni incelendiğinde, en çok hekimlerin eğitime yeterince zaman ayıramaması (\%70.7); farkındalığın yetersiz olması (\%64.6) ve eğitim programlarının yetersiz olması (\%53.1) olduğu tespit edilmiştir. "Ergin ve ark. (2014)" yapmış oldukları çalışmada akılcı ilaç kullanımı (AİK) konusunda katılımcı hekimlerin kendini yeterli görme oranı \%28.8, AİK konusunda kurs-seminer almak isteme oranı \%62.9 olarak saptanmıştır (11). Bu veriler eşliğinde her iki çalışmada da katılımcıların yaklaşık üçte ikisinin AİK konusunda eğitim almak istediği ve kendilerini mesleki eğitim konusunda yenilemeye açık ve hevesli olduklarını göstermektedir.

\section{SONUÇ VE ÖNERİLER}

Sonuç olarak, katılımcı hekimlerin yaklaşık onda dokuzu akılcı ilaç ve akılcı antibiyotik konusu hakkında bilgi sahibi olduklarını ve bu bilgilerin en önemli kaynağının eğitim almış oldukları üniversiteler olduğunu belirtmişlerdir. Buna rağmen hekimlerin antibiyotik reçete ederken bilgilerini yeteri kadar kullanmadıkları, bu konudaki farkındalıklarının artırılmasına yönelik programların yapılmasının pozitif yönde katkı sağlayacağını düşünmekteyiz. Yapılmış olan birçok çalışmada hekimler akılcı antibiyotik kullanımı konusunda kendilerini yeterli görmemektedir. Bunun en önemli nedeninin birçok tıp fakültesinde AAK konusunda eğitim verilmesine rağmen hekimlerin mezuniyet sonrası dönemde bu eğitimi kullanmakta ve hatırlamakta zorlanmalarından kaynaklandığını düşünüyoruz. Bunun nedenleri düşünüldüğünde hekimlerin hasta yoğunlukları ve muayene sürelerinin yetersiz olması akılcı olmayan ilaç kullanımına neden olmaktadır. Hekimlerin yaklaşık üçte ikisi AAK konusunda eğitim almak istediklerini belirtmişler. AAK konusunda yeterli bilgiye sahip olunmamasının nedenleri arasında en önemli nedenler hekimlerin eğitime yeteri kadar zaman ayıramamaları ve farkındalığın yetersiz olması olarak saptanmıştır. Hastanelerde hekimlere belirli aralıklarla yazılı (poster,broşür,kitapçık) ve sözlü (seminer,toplantı) kaynaklar aracılığıyla AAK konusunda farkındalığın arttırılmasına yönelik etkinlikler yapılmalı, bu sayede AAK konusunun gündemde kalması sağlanmalıdır. Bu veriler doğrultusunda hekimlerin hasta muayenesine daha uzun süreler ayırması sağlanmalı AAK konusunda yapılacak programlar çerçevesinde hekimlerin AAK konusunda mezuniyet öncesi ve mezuniyet sonrası eğitim, seminer ve kurs almaları sağlanmalıdır. Eğitimlerin belirli aralıklarla ve hekimlere zorunlu tutularak yapılmasının AAK konusunda farkındalığın sürekliliğini sağlayacağını düşünmekteyiz. Hekimlerin AAK pratiğinin arttırılması için reçete ettikleri ilaç/antibiyotik konusunda geri bildirimlerde bulunmalarının akılcı ilaç ve akılcı antibiyotik kullanımı konusunda farkındalığın artırılmasına büyük katkı sağlayacağını düşünmekteyiz.

\section{Araştırmanın Etik Yönü}

Çalışmamız Adnan Menderes Üniversitesi Tıp Fakültesi Dekanlığı Girişimsel Olmayan Klinik Araştırmalar Etik Kurulu'ndan alınan onay sonrası yapılmıştır (Tarih:12/4/2018 Karar no:9 Protokol no:2018/1376). 


\section{Çıkar Çatışması}

Yazarlar arasında çıkar çatışması yoktur.

\section{KAYNAKLAR}

1. Coşkun, Ö. (2008). Akılcı ilaç seçiminin bileşenleri“Alternatif ilaçlar arasında tercih nasıl yapılmalı? ”Arman D, Güç O(eds). Akılcı farmakoterapi (ss.32-40), Bilimsel Tıp Yayınevi, Ankara.

2. Ağalar, C. (2008). Antibiyotik seçimi için ek bileşenler, Arman D, Güç O(eds). Akılcı farmakoterapi (ss.41-80), Bilimsel Tıp Yayınevi, Ankara.

3. Akalın H. (2009). Yoğun bakım ünitesinde antibiyotik direncini azaltma ve önleme. AnkemDergisi ; 23(Ek 2):(ss.157-161).

4. Paterson, D.L. (2004). "Collateral Damage" from cephalosporin orquinolone antibiotictherapy. Clinical Infectious Diseases; 38 (Suppl 4):(ss.341-345)..

5. Saygılı, M., Özer, Ö. (2015). Hekimlerin akılcı ilaç kullanımına yönelik bilgi tutum ve davranışlarının değerlendirilmesi. Hacettepe Sağllk İdaresi Dergisi:(ss.18:35-46).

6. Şahin, H., Arsu, G., Köseli, D., Büke, Ç. (2008). Sağlık ocaklarında çalışan hekimlerinin akılcı antibiyotik kullanımıyla ilgili bilgi düzeylerinin değerlendirilmesi. Mikrobiyoloji Bülteni; 42(2):(ss.343-8).

7. Isler, B., Keske, Ş., Aksoy, M., Azap, Ö. K., Yilmaz, M., Yavuz, S. Ş. ve ark (2019). Antibiotic overconsumption and resistance in Turkey. Clinical Microbiology and Infection, 25(6):(ss. 651-653).

8. Kınalıkaya, A., Yılmaz, A., Arslan, E., Turunç, F., Yılmaz, M., Özyörük, M. ve ark (2018). Akılcı ilaç kullanımı: Düzce'de Aile Hekimlerinin bilgi ve davranışları. Türkiye Aile Hekimliği Dergisi, 22(1):(ss.20-27).

9. Kenesarı, C. K., Özçakar, N. (2016). Annelerin çocuklarında antibiyotik kullanımına ilişkin yaklaşımları: Kısa bilgilendirme ne kadar etkili?. Türkiye Aile Hekimliği Dergisi, 20(1): (ss.16-22).

10. Şahin, A. R., Teker, Ç., Ağaoğlu, P. M., Nazik, S., Ateş, S. (2019) The Role of Family Physicians in Adaptation to Rational Antibiotic Use. Online Türk Sağllk Bilimleri Dergisi, 4(4): (401-412).

11. Ergin, A., Büyükakın, B., Kortunay, S., Bozkurt A. İ. (2014). Pamukkale Üniversitesi Hastanesi Dahili Tıp Bilimlerinde Çalışan Araştırma Görevlilerinin Akılcı İlaç Kullanımı Konusundaki Bilgi ve Tutumları. Tıp Eğitim Dünyası;40(40).

12. Vançelik, S., Çalıkoğlu, O., Güraksın, A., Beyhun, E. (2006). "Pratisyen hekimlerin reçete yazımını şekillendiren faktörler ve akılcı ilaç kullanım kriterlerini önemseme durumları." Hacettepe Üniversitesi Eczacılık Fakültesi Dergisi;2:(ss.65-75).

13. Öztürk, İ. İ., Avc1, İ. Y., Coşkun, Ö., Gül, H. C., Eyigün, C. P. (2008). Birinci basamak sağlık kuruluşunda görev yapan hekimlerin s1k görülen toplum kaynaklı enfeksiyonlardaki antibiyotik seçimleri ve bunu etkileyen faktörler. Fırat Tlp Dergisi, 13(4): (ss.255-260).

14. Parlak, E., Çayır, Y., Ertürk, A. (2013). Aile Hekimlerinin akılcı antibiyotik kullanımı açısından durumları: Erzurum'dan kesitsel bir çalışma. Euras J Fam Med, 2(1): (ss.2732).

15. Machowska, A., Stålsby Lundborg, C. (2019). Drivers of irrational use of antibiotics in Europe. International journal of environmental research and public health, 16(1), ss.27. 